\title{
Hubungan tingkat kecukupan gizi, tingkat pengetahuan ibu, dan tinggi badan orangtua dengan kejadian stunting pada balita di wilayah kerja Puskesmas Tambak Wedi Surabaya
}

\section{Correlation between adequacy levels of nutrition, mother's knowledge level, and height of parents with the incidence of stunting in toddler in Puskesmas Tambak Wedi Surabaya}

\author{
Rizqita Catur Wulandari* ${ }^{1}$, Lailatul Muniroh ${ }^{2}$
}

\begin{abstract}
ABSTRAK
Latar belakang:Stunting merupakan kondisi gagal tumbuh pada balita yang berisiko menyebabkan anak mengalami kesulitan dalam mencapai perkembangan fisik dan kognitif yang optimal. Puskesmas Tambak Wedi merupakan salah satu puskemas yang mengalami peningkatan prevalensi stunting sebesar 2,7\% dari tahun 2017 hingga 2018. Peningkatan angka prevalensi mengindikasikan bahwa program pencegahan dan penanganan stunting harus dioptimalkan agar prevalensinya dapat diturunkan.

Tujuan:Menganalisis hubungan tingkat kecukupan gizi, tingkat pengetahuan ibu dan tinggi badan orangtua dengan kejadian stunting pada balita di Puskesmas Tambak Wedi.

Metode:Penelitian observasional dengan desain case control. Total populasi sebesar 1.143 balita. Besar sampel sebanyak 48 balita usia 24-59 bulan, terdiri dari 24 balita stunting dan non-stunting yang dipilih menggunakan metode simple random sampling. Variabel dependen adalah stunting. Variabel independen adalah kecukupan energi, protein, kalsium, tingkat pengetahuan ibu, dan tinggi badan orangtua. Kecukupan gizi dilakukan dengan wawancara menggunakan kuesioner SQ$F F Q$, karakteristik keluarga dan balita menggunakan lembar kuesioner, dan pengukuran tinggi badan menggunakan stadiometer. Analisis data menggunakan uji chi-square dan regresi logistik sederhana.

Hasil:Adanya hubungan tingkat kecukupan energi $(p=0,02 ; \mathrm{OR}=0,11)$, protein $(p=0,018 ; \mathrm{OR}=2,3), \operatorname{kalsium}(p=0,023 ; \mathrm{OR}=0,2)$, pengetahuan $\operatorname{ibu}(p=0,029<0,05 ; O R=-0,265)$ dengan kejadian stunting pada balita. Tinggi badan ayah $(p=0,77)$ dan ibu $(p=0,76)$ tidak berhubungan dengan kejadian stunting pada balita di Puskesmas Tambak Wedi. Kecukupan energi $(58,3 \%)$, protein(100\%), dan kalsium(58,3\%) pada balita non-stunting lebih baik daripada balita stunting. Balita dengan pengetahuan ibu baik berpeluang menurunkan risiko terjadinya stunting sebesar 0,265 kali dibandingkan balita dengan ibu pengetahuan kurang.

Kesimpulan:Tingkat kecukupan gizi (energi, protein, kalsium) dan tingkat pengetahuan ibu pada balita non-stunting lebih baik daripada balita stunting usia 24-59 bulan di wilayah kerja Puskesmas Tambak Wedi Surabaya.
\end{abstract}

Kata kunci: tingkat kecukupan gizi, tingkat pengetahuan ibu, stunting, balita

\section{ABSTRACT}

Background:Stunting is a failure to thrives in under five children condition that causes difficulty to achieves physical and cognitive development in optimal condition. Puskesmas Tambak Wedi as one of the health centers that have increased prevalence of stunting in toddlers by $2.7 \%$ from 2017 to 2018. It indicated that the prevention and management of stunting in Surabaya should be optimized so that the prevalence could be reduced.

Objectives:The objective was to analyze the correlation between adequacy level of nutrients, mother's knowledge level,and height of parents with the incidence of stunting in Puskesmas Tambak Wedi.

Methods:Observational study with a case-control design. The population was 1,143 toddlers. The sample size is 48 toddlers consisting of 24 stunting and non-stunting toddlers selected through simple random sampling. The dependent variable was stunting. The independent variable was the nutritional adequacy,mother's knowledge level, and parent's height. The data was analyzed by the chi-square test and simple logistic regression. 
Results:There were significant correlation between level of energy adequacy $(p=0.02 ; O R=0.11)$, protein $(p=0.018 ; O R=2.3)$, calcium $(p=0.023 ; O R=0.2)$, and mother's knowledge $(p=0.029 ; O R=-0.265)$ with stunting in toddler. Father's $(P=0.77)$ and mother's $(P=0.76)$ height were not correlated with stunting in a toddler. Non-stunted children were more likely to have better adequacy levels of energy(58.3\%), protein(100\%), and calcium(58.3\%) compared to stunted children. Toddlers who have a mother with good knowledge were have a lower risk of stunting by 0.265 times than toddlers whose mothers lack knowledge.

Conclusions:Adequacy levels of nutrients and level of mother knowledge in non-stunting toddlers were better than stunting toddlers aged 24-59 months in Puskesmas Tambak Wedi Surabaya.

Keywords: Nutrient adequacy, mother's level of knowledge, stunting, toddler

\author{
*Koresponden: \\ Rizqita Catur Wulandari \\ rizqita.catur.wulandari-2015@fkm.unair.ac.id \\ 1,2Departemen Gizi Kesehatan,Fakultas Kesehatan Masyarakat, Universitas Airlangga
}

\section{PENDAHULUAN}

Stunting (pendek) merupakan kondisi gagal tumbuh pada balita yang berisiko menyebabkan anak mengalami kesulitan dalam mencapai perkembangan fisik dan kognitif yang optimal ${ }^{1,2}$. Stunting ditetapkan dengan nilai z-score tinggi badan menurut usia (z-score TB/U) <-2 SD berdasarkan standar World Health Organization $(\mathrm{WHO})^{3}$. Tinggi badan yang rendah pada masa anak-anak digunakan sebagai indikator jangka panjang untuk gizi kurang pada anak akibat kualitas dan kuantitas makanan yang tidak cukup dan disertai dengan penyakit infeksi yang dialami anak ${ }^{1,4}$. Menurut WHO (2010), Indonesia masuk dalam kategori wilayah dengan masalah stunting yang tinggi (30-39\%). Hal tersebut dikarenakan prevalensi stunting di Indonesia pada tahun 2018 mencapai angka $30,8 \%{ }^{6}$. Tingginya angka balita stunting di Indonesia menandakan bahwa hal tersebut masih menjadi permasalahan kesehatan nasional.

Permasalahan stunting umumnya dihubungkan dengan asupan gizi sebelumnya yang tidak baik. Asupan zat gizi makro (energi dan protein) dan zat gizi mikro yang rendah terutama pada masa pertumbuhan dapat menghambat proses tumbuh kembang balita dan menyebabkan stunting (pendek). Balita yang memiliki asupan energi dan protein yang kurang berisiko mengalami stunting dibandingkan balita yang asupan energi dan proteinnya cukup ${ }^{7}$. Protein merupakan zat gizi yang berperan dalam pertumbuhan dan pemeliharaan jaringan tubuh serta menggantikan sel-sel yang mati. Anak yang mengalami defisiensi protein yang berlangsung lama akan berdampak pada pertumbuhan tinggi badan dan perkembanga otak yang melambat ${ }^{8,1}$. Asam amino triptofan dan tirosin yang terdapat dalam protein berfungsi sebagai prekursor neurotrasmitter dalam tumbuh kembang otak ${ }^{9}$. Pada masa pertumbuhan juga terjadi proses mineralisasi tulang yang sangat tinggi. Salah satu zat gizi mikro yang berperan pada proses tersebut adalah kalsium. Apabila pada masa pertumbuhan anak rendah terhadap asupan kalsiumnya dapat mengakibatkan rendahnya mineralisasi matriks deposit tulang baru dan disfungsi osteoblast ${ }^{10}$. Asupan kalsium yang rendah ditemukan pada balita usia 2-5 tahun yang mengalami gangguan pertumbuhan linear (stunting) $)^{11}$.
Rendahnya pendidikan disertai dengan rendahnya pengetahuan gizi juga sering dihubungkan dengan kejadian malnutrisi pada balita ${ }^{12}$. Pengetahuan ibu dalam upaya mengatur, mengetahui dan merancang menu makanan yang sehat dan bergizi bagi dirinya serta keluarga sangat penting dalam upaya pemenuhan dan peningkatan mutu gizi anak yang diperlukan. Oleh karena itu, pemahaman dan pengetahuan ibu tentang gizi merupakan salah satu faktor yang mempengaruhi tingginya prevalensi stunting pada balita ${ }^{13}$.

Tinggi badan orang tua juga berpengaruh terhadap kejadian stunting pada balita. Gen dalam kromosom yang membawa sifat pendek yang dimiliki oleh salah satu maupun kedua orang tua dengan tinggi badan pendek karena kondisi patologi (seperti defisiensi hormon pertumbuhan) akan meningkatkan peluang anak mewarisi gen tersebut dan tumbuh menjadi stunting. Namun, apabila orang tua pendek akibat kekurangan gizi atau penyakit, kemungkinan anak dapat tumbuh dengan tinggi badan normal selama anak tersebut tidak terpapar faktor risiko yang lain ${ }^{14}$.

Wilayah kerja Puskesmas Tambak Wedi merupakan salah satu puskesmas yang mengalami peningkatan angka kejadian balita stunting di wilayahnya. Pada tahun 2018, prevalensi stunting di wilayah kerja Puskesmas Tambak Wedi sebesar 18,9\% meningkat dari tahun sebelumnya yaitu sebesar $16,2 \%$. Berdasarkan data bulan timbang pada bulan Agustus 2019 menunjukkan bahwa jumlah balita di wilayah kerja Puskesmas Tambak Wedi sebesar 1.143 balita dan sebanyak $216(18,9 \%)$ balita yang mengalami stunting.

Stunting baru dapat diketahui setelah umur 2 tahun $^{2}$. Anak dengan gangguan pertumbuhan linear (pendek) berisiko mengalami perkembangan kognitif motorik, dan verbal yang tidak optimal ${ }^{15}$. Dampak jangka panjangnya, anak akan mengalami penurunan kesehatan reproduksi, kapasitas kerja dan performa yang kurang optimal saat masa sekolah, postur tubuh yang pendek saat dewasa serta mengalami penurunan produktivitas dan kapasitas kerja ${ }^{16}$. Kondisi ini juga sulit untuk dapat pulih kembali dan tidak dapat berkembang jika kondisi buruk terjadi pada masa golden period perkembangan otak (0-2 tahun). Hal tersebut diakibatkan pada masa tersebut terjadi perkembangan otak yang pesat karena 80-90\% jumlah sel otak terbentuk semenjak masa dalam 
kandungan sampai usia 2 (dua) tahun dan perkembangan otaknya mencapai $80 \%$ otak dewasa ${ }^{17,18}$. Berdasarkan uraian diatas, peneliti ingin meneliti hubungan tingkat kecukupan energi, protein, dan kalsium, tingkat pengetahuan ibu dan tinggi badan orangtua dengan stunting pada balita usia 24-59 bulan di wilayah kerja Puskesmas Tambak Wedi.

\section{METODE}

Penelitian ini menggunakan rancangan penelitian observasional dan desain penelitian case control. Populasi dari penelitian ini terdiri dari dua kelompok yaitu populasi kasus sebanyak 216 balita dan populasi kontrol sebanyak 927 balita. Sampel dalam penelitian ini dipilih secara acak yaitu sebesar 48 balita yang terdiri dari 24 balita stunting dan 24 balita normal (nonstunting) berdasarkan rumus Lemeshow ${ }^{19}$. Pengambilan sampel dilakukan dengan teknik probabilitas yaitu simple random sampling yang sebelumnya telah dilakukan pengelompokan menjadi kelompok stunting dan nonstunting.

Penelitian ini dilaksanakan pada bulan Mei dan Juni tahun 2019 di wilayah kerja Puskesmas Tambak Wedi Kota Surabaya. Data primer yang dikumpulkan meliputi karakteristik orang tua (umur, pendidikan, pekerjaan, tinggi badan, tingkat pengetahuan ibu), karakteristik balita (umur, jenis kelamin, tinggi badan), asupan energi, protein, dan kalsium. Pengumpulan data dilakukan dengan teknik wawancara dan teknik pengukuran langsung. Teknik wawancara dilakukan pada ibu/pengasuh balita untuk mengetahui karakteristik keluarga, tingkat pengetahuan ibu dengan kuesioner yang terdiri dari 15 pertanyaan serta asupan zat gizi balita dengan bantuan lembar form SQ-FFQ. Pengetahuan ibu selanjutnya diberi skor 1 jika benar dan 0 jika salah. Total skor kemudian dikelompokkan menjadi kurang $(<60 \%)$, sedang $(60-80 \%)$, dan baik $(>80 \%)^{20}$. Tingkat kecukupan zat gizi balita selanjutnya dianalisis dengan bantuan software komputer. Hasil dari analisis tersebut akan dibandingkan dengan cut off point kecukupan gizi makro dan mikro. Tingkat kecukupan zat gizi makro (energi dan protein) dibandingkan dengan AKG yaitu < 77\% nilai Angka Kecukupan Gizi (AKG) untuk kategori kurang dan $\geq 77 \%$ nilai AKG untuk kategori cukup. Tingkat kecukupan kalsium dibandingkan dengan Estimated Average Requirements (EAR) yaitu kurang jika asupan $\angle E A R$ dan cukup jika $\geq E^{2}{ }^{21}$. Teknik pengukuran langsung dilakukan dengan mengukur tinggi badan balita dan orangtua menggunakan alat stadiometer untuk mengetahui indikator TB/ $U$ dalam penentuan stunting. Data sekunder meliputi jumlah populasi balita, jumlah balita stunting dan non-stunting di wilayah kerja Puskesmas Tambak Wedi.

Penelitian ini menggunakan analisis data univariat dan bivariat. Gambaran atau distribusi karakteristik balita dan keluarga dianalisis menggunakan analisis univariat, sedangkan analisis bivariat digunakan untuk analisis hubungan variabel. Uji chi-square untuk skala data nominal dan uji regresi logistik sederhana untuk skala data ordinal. Analisis regresi sederhana merupakan analisis statistik yang mempelajari hubungan antara dua variabel yaitu satu variabel dependen dan independen. Analisis pada uji regresi menyangkut beberapa perhitungan statistik seperti uji signifikansi, anova, dan penentuan hipotesis ${ }^{22}$. Peneliti telah mendapat ijin penelitian dari Komiite Etik FKM Universitas Airlangga dengan nomor ijin 124/EA/KEPK/2019.

\section{HASIL DAN PEMBAHASAN}

\section{Karakteristik Balita}

Usia balita diketahui berdasarkan wawancara melalui lembar kuesioner dan dinyatakan dalam satuan bulan. Usia balita merupakan periode penting dalam tumbuh kembang anak. Berdasarkan Tabel 1, diketahui bahwa sebagian besar balita pada kelompok kasus berusia 48-59 bulan yaitu sebanyak 54,2\%, dibandingkan dengan balita pada kelompok kontrol yang sebagian besar berusia $24-47$ bulan yaitu sebanyak $54,2 \%$.

Jenis kelamin balita didasarkan atas wawancara melalui lembar kuesioner penelitian. Tabel 1 menunjukkan bahwa baik balita kelompok kasus maupun kontrol keduanya sama-sama didominasi oleh balita berjenis kelamin perempuan. Hal tersebut serupa dengan penelitian lain yang menunjukkan bahwa angka kejadian stunting ditemukan lebih banyak pada balita perempuan daripada balita laki-laki di Kelurahan Tambak Wedi Surabaya ${ }^{23}$.

Tabel 3 menunjukkan bahwa pada kelompok kasus ditemukan lebih banyak balita dengan tingkat kecukupan gizi yang kurang dibandingkan balita pada kelompok kontrol. Tingkat kecukupan gizi didasarkan atas jumlah asupan gizi ke dalam tubuh yang berasal dari sumber makanan danminuman sehari-hari oleh sampel.Tingkat kecukupan energi $(95,8 \%)$, protein $(54,2 \%)$, dan kalsium $(87,5 \%)$ pada balita stunting masing-masing diketahui memiliki tingkat asupan energi, protein, dan kalsium yang kurang dari yang dianjurkan.

Balita merupakan salah satu kelompok rentan mengalami kurang gizi dan berdampak pada kejadian stunting, khususnya balita berusia 2-5 tahun karena kebutuhan gizinya semakin meningkat dan ASI tidak mampu mencukupi kebutuhan balita, sehingga diperlukan asupan zat gizi dari makanan sehari-hari. Adanya selera khusus terhadap kesukaan dan cita rasa makanan pada usia ini juga menjadi faktor balita mengalami kekurangan zat gizi. Penelitian di Surakarta menunjukkan balita usia 2-5 tahun cenderung lebih menyukai jajanan seperti chiki, permen, es, dan lain-lain, dimana makanan tersebut mengandung energi dan protein yang rendah serta kaya akan bahan aditif ${ }^{24}$.

\section{Karakteristik Orangtua}

Distribusi karakteristik orangtua dapat dilihat pada Tabel 1. Tabel 1 menunjukkan sebagian besar usia ayah dan ibu pada kelompok kasus (stunting) maupun kontrol (non-stunting) berada pada rentang usia 26-35 tahun. Sebanyak $66,7 \%$ ayah dan $91,7 \%$ ibu pada kelompok kasus berusia 26-35 tahun. Berbeda halnya pada kelompok kontrol, jumlah ayah dan ibu yang berada pada rentang usia $26-35$ tahun sebesar $54,2 \%$ ayah dan $79,2 \%$ ibu.

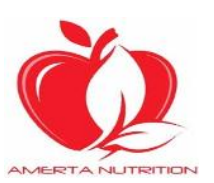


Tabel 1. Karakteristik balita dan orangtua

\begin{tabular}{|c|c|c|c|c|}
\hline \multirow{2}{*}{ Variabel } & \multicolumn{2}{|c|}{ Stunting } & \multicolumn{2}{|c|}{ Normal } \\
\hline & $\mathrm{n}$ & $\%$ & $\mathrm{n}$ & $\%$ \\
\hline \multicolumn{5}{|l|}{ Jenis kelamin Balita } \\
\hline Laki-laki & 11 & 45,8 & 10 & 41,7 \\
\hline Perempuan & 13 & 54,2 & 14 & 58,3 \\
\hline \multicolumn{5}{|l|}{ Usia Balita } \\
\hline $24-47$ bulan & 11 & 45,8 & 13 & 54,2 \\
\hline 48-59 bulan & 13 & 54,2 & 11 & 45,8 \\
\hline \multicolumn{5}{|l|}{ Usia Ayah } \\
\hline $26-35$ tahun & 16 & 66,7 & 13 & 54,2 \\
\hline $36-45$ tahun & 8 & 33,3 & 11 & 45,8 \\
\hline \multicolumn{5}{|l|}{ Usia Ibu } \\
\hline 26-35 tahun & 22 & 91,7 & 19 & 79,2 \\
\hline $36-45$ tahun & 2 & 8,3 & 5 & 20,8 \\
\hline \multicolumn{5}{|l|}{ Tinggi badan ayah } \\
\hline Pendek $(<162 \mathrm{~cm})$ & 11 & 45,8 & 12 & 50 \\
\hline Normal ( $\geq 162 \mathrm{~cm})$ & 13 & 54,2 & 12 & 50 \\
\hline \multicolumn{5}{|l|}{ Tinggi badan ibu } \\
\hline Pendek $(<150 \mathrm{~cm})$ & 9 & 37,5 & 8 & 33,3 \\
\hline Normal $(\geq 150 \mathrm{~cm})$ & 15 & 62,5 & 16 & 66,7 \\
\hline \multicolumn{5}{|l|}{ Pendidikan Ayah } \\
\hline Dasar & 16 & 66,7 & 11 & 45,8 \\
\hline Menengah & 8 & 33,3 & 13 & 54,2 \\
\hline Tinggi & 0 & 0 & 0 & 0 \\
\hline \multicolumn{5}{|l|}{ Pendidikan Ibu } \\
\hline Dasar & 18 & 75 & 11 & 45,8 \\
\hline Menengah & 6 & 25 & 13 & 54,2 \\
\hline Tinggi & 0 & 0 & 0 & 0 \\
\hline \multicolumn{5}{|l|}{ Pekerjaan Ayah } \\
\hline Karyawan & 15 & 62,5 & 17 & 70,8 \\
\hline Wiraswasta & 7 & 29,2 & 4 & 16,7 \\
\hline Pedagang & 0 & 0 & 0 & 0 \\
\hline Petani & 0 & 0 & 1 & 4,2 \\
\hline Tidak Bekerja & 0 & 0 & 0 & 0 \\
\hline Lainnya & 2 & 8,3 & 2 & 8,3 \\
\hline \multicolumn{5}{|l|}{ Pekerjaan Ibu } \\
\hline Karyawan & 0 & 0 & 1 & 4,2 \\
\hline Wiraswasta & 0 & 0 & 2 & 8,3 \\
\hline Pedagang & 3 & 12,5 & 0 & 0 \\
\hline Petani & 0 & 0 & 0 & 0 \\
\hline Tidak Bekerja & 21 & 87,5 & 21 & 87,5 \\
\hline Lainnya & 0 & 0 & 0 & 0 \\
\hline
\end{tabular}

Menurut Depkes (2009), usia 26-35 tahun tergolong dalam kategori dewasa awal. Pada masa tersebut selain memiliki peran sebagai pasangan hidup, juga memiliki peran lain yang sangat penting yaitu sebagai orangtua yang selalu menyediakan waktu untuk mendidik dan merawat anak. Pada usia ini, orangtua diharapkan dapat menstimulasi tumbuh kembang anak dan memfokuskan pada pola pengasuhan terhadap anak sehingga anak dapat terhindar dari masalah gizi ${ }^{25}$.

Kualifikasi tingkat pendidikan dibagi menjadi tiga yaitu tamat pendidikan dasar (Tamat SD/MI/SMP/MTs/sederajat), menengah (Tamat SMA/MA/SMK/sederajat) dan tinggi (Tamat Perguruan Tinggi). Berdasarkan hasil penelitian, dapat diketahui bahwa sebagian besar balita stunting ditemukan pada ayah $(66,7 \%)$ dan ibu (75\%) yang tamat pendidikan dasar, berbeda halnya dengan balita non-stunting sebagian besar ditemukan pada ayah $(54,2 \%)$ dan ibu $(54,2 \%)$ yang berpendidikan menengah.

Karakteristik keluarga seperti pendidikan dan pekerjaan orangtua merupakan faktor tidak langsung yang mempengaruhi stunting. Kejadian stunting pada balita cenderung terjadi pada ayah dan ibu dengan pendidikan rendah ${ }^{26}$. Tingkat pendidikan akan berpengaruh terhadap tingkat pengetahuan seseorang. Orang yang berpendidikan tinggi khususnya dalam hal ini adalah ayah dan ibu akan berpengaruh pada kecenderungan untuk memilih makanan yang lebih baik dalam jumlah dan mutu untuk balitanya dibandingkan dengan orangtua yang berpendidikan rendah ${ }^{27}$.

Berdasarkan hasil penelitian juga diketahui bahwa sebagian besar balita stunting maupun non- 
stunting ditemukan pada ayah yang bekerja sebagai karyawan. Hal ini dapat terjadi dikarenakan ayah tidak mengambil peran yang dominan dalam keputusan penentuan kebutuhan gizi karena penyediaan kebutuhan gizi diperankan oleh ibu ${ }^{28}$. Begitu halnya dengan pekerjaan ibu, sebagian besar ibu di wilayah kerja Puskesmas Tambak Wedi adalah sebagai ibu rumah tangga (tidak bekerja) ${ }^{29}$. Banyak ibu yang tidak bekerja ditemukan pada balita stunting $(87,5 \%)$ dan non-stunting (87,5\%). Meskipun ibu yang tidak bekerja memiliki lebih banyak waktu untuk mengasuh anak namun jika pola asuh yang diberikan kurang baik seperti dalam pola makan kurang diperhatikan maka akan menyebabkan terjadinya masalah gizi pada balita ${ }^{30}$.

Pengetahuan ibu didasarkan atas jawaban ibu pada lembar kuesioner pengetahuan yang berkaitan dengan gizi balita dan faktor risiko stunting. Berdasarkan hasil penelitian, diketahui bahwa sebagian besar balita stunting (58,3\%) lebih banyak ditemukan pada ibu dengan tingkat pengetahuan yang sedang, dibandingkan dengan balita non stunting $(54,2 \%)$ yang banyak ditemukan pada ibu dengan tingkat pengetahuan baik.
Praktek pengasuhan yang kurang baik termasuk rendahnya pengetahuan ibu mengenai gizi dan kesehatan sebelum, saat kehamilan dan setelah ibu melahirkan merupakan salah satu faktor penyebab stunting pada balita ${ }^{2}$.

Distribusi tinggi badan orangtua dapat dilihat pada Tabel 2. Tabel 2 menunjukkan bahwa selisih ratarata tinggi badan ayah pada kelompok stunting lebih rendah $0,4 \mathrm{~cm}$ dibandingkan kelompok non stunting. Berbeda dengan ibu yang memiliki selisih rata-rata tinggi badan sebesar $1,7 \mathrm{~cm}$ lebih tinggi pada kelompok stunting. Tinggi badan ibu dalam hal ini termasuk dalam faktor genetik, faktor ini bukan satu-satunya faktor yang mempengaruhi tumbuh kembang pada balita. Terdapat hal lain yang juga mempengaruhi terjadinya stunting pada anak yaitu kekurangan gizi pada masa kehamilan ibu yang bisa menyebabkan anak memiliki postur tubuh yang pendek ${ }^{31}$. Rata-rata tinggi badan ayah dan ibu pada balita stunting maupun non-stunting tergolong dalam kategori normal. Selain itu sebagian besar tinggi badan ayah dan ibu pada kelompok stunting maupun non stunting berada pada kategori normal.

Tabel 2. Distribusi asupan zat gizi balita dan tinggi badan orangtua

\begin{tabular}{llrllll}
\hline \multirow{2}{*}{ Variabel } & \multicolumn{3}{c}{ Stunting } & \multicolumn{3}{c}{ Normal } \\
\cline { 2 - 7 } & \multicolumn{1}{c}{$-x \pm$ SD } & Min & Maks & ${ } x \pm$ SD & Min & Maks \\
\hline Asupan Zat Gizi & & & & & & \\
Energi (kkal) & $671,1 \pm 214,3$ & 391,8 & 1220,7 & $932,1 \pm 230,0$ & 548,7 & 1500,8 \\
Protein (g) & $23,9 \pm 3,3$ & 19,9 & 33,4 & $32,0 \pm 6,5$ & 20,2 & 47,7 \\
Kalsium (mg) & $302,8 \pm 178,4$ & 108,8 & 814,1 & $456,7 \pm 261,3$ & 115,1 & 1059,3 \\
Tinggi Badan Orangtua & & & & & & \\
Tinggi badan Ayah (cm) & $163,8 \pm 7,9$ & 150 & 180 & $164,2 \pm 7,12$ & 150 & 181 \\
Tinggi badan Ibu (cm) & $153,4 \pm 6,63$ & 145 & 169 & $151,7 \pm 5,79$ & 141 & 163 \\
\hline
\end{tabular}

\section{Hubungan Antar Variabel}

Hasil analisis kecukupan energi dengan stunting diperoleh $p$-value sebesar 0,02 sehingga menandakan bahwa terdapat hubungan yang signifikan diantara keduanya. Tabel 4 menunjukkan bahwa balita dengan tingkat kecukupan energi kurang berisiko mengalami stunting sebesar 0,11 kali daripada balita dengan tingkat kecukupan energi cukup. Berdasarkan Tabel 3 hampir seluruh balita stunting memiliki tingkat kecukupan energi yang kurang. Selama penelitian berlangsung dapat diketahui bahwa beberapa orangtua khususnya ibu dalam memberikan makanan kurang dari kebutuhan balita. Hal tersebut dikarenakan ibu yang menuruti keinginan anak dengan menghentikan pemberian makan bila anak sudah tidak mau makan makanan yang diberikan. Tingkat kecukupan energi yang kurang merupakan faktor risiko terjadinya stunting pada balita $^{32}$. Energi merupakan salah satu zat gizi yang sangat penting diperlukan dalam mendukung pertumbuhan dan perkembangan anak sesuai dengan grafik pertumbuhannya agar tidak terjadi gagal tumbuh (growth faltering) sehingga dapat menyebabkan stunting ${ }^{1}$.

Nilai $p$-value tingkat kecukupan protein diperoleh nilai sebesar 0,018 yang berarti ada hubungan antara tingkat kecukupan protein dengan kejadian stunting pada balita di wilayah kerja Puskesmas Tambak Wedi Kota Surabaya. Balita akan berisiko mengalami stunting 2,3 kali lebih besar pada balita yang memiliki tingkat kecukupan protein kurang. Tabel 3 menunjukkan bahwa tingkat kecukupan protein yang kurang lebih banyak ditemukan pada kelompok balita stunting, sedangkan pada balita non-stunting, keseluruhan balita memiliki tingkat kecukupan protein yang cukup. Saat observasi di lapangan, ditemukan bahwa terdapat beberapa balita yang menjadikan kacang-kacangan sebagai makanan selingan di rumah, sehingga dapat menambah pemenuhan jumlah asupan protein balita sehari-hari. Penelitian ini sejalan dengan penelitian di Kota Blitar yang mengemukakan bahwa salah satu penyebab stunting pada balita usia 25-60 bulan di Kecamatan Sukorejo Kota Blitar adalah asupan protein yang kurang ${ }^{26}$. Protein berperan dalam proses pertumbuhan dan perbaikan sel - sel. Protein yang optimal akan menjalankan fungsinya dalam proses pertumbuhan ${ }^{8}$. Selain itu, asupan protein yang cukup juga dapat berpengaruh pada sistem kekebalan tubuh agar bekerja dengan baik ${ }^{33}$.

Berdasarkan Tabel 3 juga diketahui bahwa terdapat hubungan yang signifikan antara tingkat kecukupan kalsium dengan stunting ( $p$-value $<0,05$ ). Berdasarkan uji statistik chi-square, diketahui bahwa balita dengan tingkat kecukupan kalsium yang kurang memiliki risiko sebesar 0,2 kali untuk mengalami stunting. Tabel 3 menampilkan bahwa rata-rata asupan kalsium kelompok balita stunting masih dibawah angka 
kecukupan kalsium balita usia $24-59$ bulan yaitu 347,5 mg untuk balita usia 24-36 bulan dan 416,7 mg untuk balita usia 37-59 bulan. Sebanyak $87,5 \%$ balita memiliki tingkat kecukupan kalsium yang kurang. Kalsium sangat dibutuhkan pada masa pertumbuhan anak karena pada masa pertumbuhan terjadi proses mineralisasi tulang yang sangat tinggi. Ketika pada masa pertumbuhan anak rendah terhadap asupan kalsiumnya dapat mengakibatkan rendahnya proses mineralisasi matriks deposit tulang baru dan disfungsi osteoblast ${ }^{10}$. Hubungan yang bermakna antara tingkat asupan kalsium dengan kejadian stunting juga ditunjukkan oleh penelitian lain, dimana menurut penelitian tersebut defisiensi kalsium akan berimplikasi pada gangguan pertumbuhan tinggi badan atau stunting pada balita ${ }^{34}$.

Tabel 3. Hasil analisis hubungan antar variabel dengan uji statistik chi-square

\begin{tabular}{|c|c|c|c|c|c|c|c|c|}
\hline \multirow{2}{*}{ Variabel } & \multicolumn{2}{|c|}{ Kasus } & \multicolumn{2}{|c|}{ Kontrol } & \multirow{2}{*}{$p$ value } & \multirow{2}{*}{ OR } & \multicolumn{2}{|c|}{$95 \% \mathrm{Cl}$} \\
\hline & $\mathrm{n}$ & $\%$ & $\mathrm{n}$ & $\%$ & & & Lower & Upper \\
\hline \multicolumn{9}{|c|}{ Tingkat Kecukupan Energi } \\
\hline Kurang & 23 & 95,8 & 10 & 41,7 & \multirow{2}{*}{0,02} & \multirow{2}{*}{0,11} & \multirow{2}{*}{0,012} & \multirow{2}{*}{0,94} \\
\hline Cukup & 1 & 4,2 & 14 & 58,3 & & & & \\
\hline \multicolumn{9}{|c|}{ Tingkat Kecukupan Protein } \\
\hline Kurang & 13 & 54,2 & 0 & 0 & \multirow{2}{*}{0,018} & \multirow{2}{*}{2,3} & \multirow{2}{*}{1,62} & \multirow{2}{*}{3,17} \\
\hline Cukup & 11 & 45,8 & 24 & 100 & & & & \\
\hline \multicolumn{9}{|c|}{ Tingkat Kecukupan Kalsium } \\
\hline Kurang & 21 & 87,5 & 10 & 41,7 & \multirow{2}{*}{0,023} & \multirow{2}{*}{0,2} & \multirow{2}{*}{0,05} & \multirow[t]{2}{*}{0,86} \\
\hline Cukup & 3 & 12,5 & 14 & 58,3 & & & & \\
\hline \multicolumn{9}{|l|}{ Tinggi badan ayah } \\
\hline Pendek & 11 & 45,8 & 12 & 50 & \multirow{2}{*}{0,77} & \multirow{2}{*}{1,18} & \multirow{2}{*}{0,38} & \multirow{2}{*}{3,67} \\
\hline Normal & 13 & 54,2 & 12 & 50 & & & & \\
\hline \multicolumn{9}{|l|}{ Tinggi badan ibu } \\
\hline Pendek & 9 & 37,5 & 8 & 33,3 & \multirow[b]{2}{*}{0,76} & \multirow{2}{*}{0,83} & \multirow{2}{*}{0,26} & \multirow[b]{2}{*}{2,72} \\
\hline Normal & 15 & 62,5 & 16 & 66,7 & & & & \\
\hline
\end{tabular}

Hasil analisis hubungan tingkat pengetahuan ibu dengan kejadian stunting menunjukkan hubungan yang signifikan ( $p$-value $<0,05)$ pada balita di wilayah kerja Puskesmas Tambak Wedi Kota Surabaya. Hal ini menunjukkan bahwa balita dengan ibu yang memiliki tingkat pengetahuan baik berpeluang menurunkan risiko terjadinya stunting sebesar 0,265 kali dibandingkan balita dengan ibu yang memiliki tingkat pengetahuan kurang. Faktor tingkat pengetahuan ibu pada penelitian ini diduga berkaitan dengan tingkat pendidikan ibu, dimana sebagian besar (75\%) pendidikan ibu pada kelompok kasus adalah tamat tingkat pendidikan dasar. Ibu dengan pengetahuan gizi cukup dan baik berpeluang akan menyediakan makan dengan jenis dan jumlah yang sesuai untuk mengoptimalkan proses tumbuh dan kembang balita di periode emasnya ${ }^{35}$.

Tabel 4. Hasil analisis hubungan antar variabel dengan uji regresi logistik sederhana

\begin{tabular}{lcccccccc}
\hline \multirow{2}{*}{ Variabel } & \multicolumn{3}{c}{ Kasus } & \multicolumn{2}{c}{ Kontrol } & \multirow{2}{*}{$t$} & \multirow{2}{*}{$p$ value } & \multirow{2}{*}{ B } \\
\cline { 2 - 5 } & $\mathrm{n}$ & $\%$ & $\mathrm{n}$ & $\%$ & & & \multirow{2}{*}{$-0,265$} \\
\hline Kurang $(<60 \%)$ & 3 & 12,5 & 0 & 0 & & & \\
Sedang (60-80\%) & 14 & 58,3 & 11 & 45,8 & 2,253 & 0,029 & \\
Baik (>80\%) & 7 & 29,2 & 13 & 54,2 & & & \\
\hline
\end{tabular}

Berdasarkan uji statistik chi-square pada Tabel 3 menunjukkan bahwa tidak terdapat hubungan yang signifikan antara tinggi badan orangtua dengan stunting ( $p$-value $\geq 0,05)$. Tinggi badan ayah dan ibu bukan merupakan faktor risiko kejadian stunting pada penelitian ini. Hal ini dapat disebabkan karena tinggi badan ayah dan ibu pada kelompok kasus $(54,2 \%$ ayah dan $62,5 \%$ ibu) maupun kontrol (50\% ayah dan $66,7 \%$ ibu) sebagian besar adalah normal sehingga perbedaan tersebut menjadi tidak bermakna. Tinggi badan anak selain dipengaruhi oleh faktor genetik juga dipengaruhi oleh faktor non-genetik. Faktor non-genetik tersebut meliputi asupan yang dikonsumsi (selama ibu hamil maupun asupan pada balita) dan riwayat penyakit anak. Faktor non-genetik dapat mempengaruhi pertumbuhan anak, yang mana apabila faktor tersebut kurang optimal dapat menghambat capaian tinggi badan sesuai potensi genetik (tinggi badan orang tua) $)^{36,37}$.

\section{KESIMPULAN}

Berdasarkan hasil penelitian dapat diketahui bahwa sebagian besar balita stunting berusia 4-5 tahun dan berjenis kelamin perempuan. Selain itu, sebagian besar balita stunting maupun tidak stunting memiliki ayah yang bekerja sebagai karyawan dan ibu yang tidak bekerja. Pendidikan ayah dan ibu pada kelompok balita stunting didominasi oleh pendidikan dasar, sedangkan pada kelompok balita non-stunting, ayah dan ibunya berpendidikan menengah. Tinggi badan ayah dan ibu pada kelompok stunting maupun non stunting berada pada kategori normal. Berdasarkan hasil penelitian juga dapat disimpulkan pula bahwa tingkat kecukupan energi, protein, kalsium dan tingkat pengetahuan ibu merupakan faktor risiko kejadian stunting pada balita di Wilayah Kerja Puskesmas Tambak Wedi. Masing-masing kecukupan zat gizi yang kurang meliputi tingkat 
kecukupan energi 0,11 kali; protein 2,3 kali; kalsium 0,2 kali berisiko lebih besar untuk mengalami stunting. Sedangkan tingkat pengetahuan ibu yang baik berpeluang 0,265 kali menurunkan risiko terjadinya stunting dibandingkan balita dengan ibu pengetahuan kurang.

\section{ACKNOWLEDGEMENT}

Peneliti mengucapkan terimakasih kepada Badan Kesatuan Bangsa dan Politik Surabaya, Dinkes Kota Surabaya, dan Kepala Puskesmas Tambak Wedi Surabaya yang telah mengizinkan penelitian ini sehingga dapat terselenggara. Tak lupa juga kepada ahli gizi di puskesmas setempat yang telah membantu dalam pelaksanaannya, ibu-ibu yang telah menjadi responden pada penelitian ini, serta teman-teman yang telah membantu dan mendukung penelitian hingga selesai.

\section{REFERENSI}

1. Pusdatin. Situasi Gizi di Indonesia. (Kementrian Kesehatan RI, 2016).

2. Tim Nasional Percepatan Penanggulangan Kemiskinan. 100 Kabupaten/Kota Prioritas untuk Intervensi Anak Kerdil (Stunting). (2017).

3. World Health Organization. WHO Child Growth Standards. (WHO Press., 2005).

4. Shrimpton, R. et al. Worldwide timing of growth faltering: implications for nutritional interventions. Pediatrics 107, 1-7 (2001).

5. World Health Organization. Country Profile Indicators: Interpretation Guide. Nutrition Landscape Information System (NLIS). (WHO Press, 2010).

6. Balitbangkes. Riset Kesehatan Dasar (Riskesdas) 2018. (2018).

7. Fitri. Berat Lahir Sebagai Faktor Dominan Terjadinya Stunting Pada Balita $(12-59$ BI) di Sumatra (Analisis Data Riskesdes, 2010). (Universitas Indonesia, 2012).

8. Almatsier, S. Prinsip Dasar Ilmu Gizi. (Gramedia Pustaka Utama, 2010).

9. Georgieff, M. Nutrition and the developing brain: Nutrient priorities and measurement. Am. J. Clin. Nutr. 85, 614-620 (2007).

10. Khairy, S. A. M. ., Mattar, M. K., Refaat, L. A. M. \& El-Sherbeny, S. A. Plasma micronutrient levels of stunted Egyptian school age children. Kasr EI Aini Med J. 16, (2010).

11. Stuijvenberg, M. E. et al. Low Intake of Calcium and Vitamin D, but Not Zinc, Iron or Vitamin A, is Associated with Stunting in 2-5 Years Old Children. Nutrition 31, 841-846 (2015).

12. Nashikhah, R. \& Margawati, A. Faktor Risiko Kejadian Stunting Pada Balita Usia 24-36 Bulan di Kecamatan Semarang Timur. J. Nutr. Coll. 1, 176-184 (2012).

13. Uliyanti, Tamtomo, D. G. \& Anantanyu, S. Faktor yang Berhubungan dengan Kejadian Stunting
Pada Balita Usia 24-59 Bulan. J. Vokasi Kesehat. 3, 67-77 (2017).

14. Rahayu, L. S. Associated Of Height Of Parents With Changes Of Stunting Status From 6-12 Months to 3-4 Years. (Universitas Gajah Mada, 2011).

15. World Health Organization. Childhood Stunting: Context, Causes and Consequences WHO Conceptual framework. (WHO Press, 2013).

16. World Health Organization. Stunted Growth and Development. Matern. Child Nutr. 9, 27-45 (2017).

17. Gibney, M. J. Gizi Kesehatan Masyarakat. (EGC, 2009).

18. Gantham, S. \& Gregor, M. Child Development in Developing Countries 1. Repr. Lancet 369, 61 (2007).

19. Lemeshow, S., Hosmer, D., Klar, J. \& Lwanga, S. Adequacy of Sample Size in Health Studies. (John Wiley Sons Ltd, 1990).

20. Khomsan, A. Teknik Pengukuran Pengetahuan Gizi. (Institut Pertanian Bogor, 2000).

21. Gibson, R. S. Principles of Nutritional Assessment. (Oxford University Press, 2005).

22. Yuliara, I. made. Modul Regresi Linier Sederhana. (2016).

23. Oktiva, B. R. \& Adriani, M. Perbedaan Kadar Zinc Rambut pada Anak Stunting dan Non Stunting dengan Usia 12-24 bulan. Amerta Nutr. 1, 133142 (2017)

24. Sunarti \& Nugrohowati, A. K. Korelasi Status Gizi, Asupan Zat Besi Dengan Kadar Feritin Pada Anak Usia 2-5 Tahun Di Kelurahan Semanggi Surakarta. J. Kesehat. Masy. 8, 11-17 (2014).

25. Hurlock, B. \& Elizabeth. Perkembangan Anak Jilid 2. (Erlangga, 2013).

26. Mugianti, S., Mulyadi, A., Anam, A. K. \& Najah, Z. L. Faktor Penyebab Anak Stunting Usia 25-60 bulan di Kecamatan Sukorejo Kota Blitar. J. Ners dan Kebidanan 5, 268-278 (2018).

27. Notoatmodjo, S. Ilmu Perilaku Kesehatan. (PT. Rineka Cipta, 2010).

28. Wahdah, S., Juffrie, M. \& Huriyati, E. Faktor risiko kejadian stunting pada anak umur 6-36 bulan di Wilayah Pedalaman Kecamatan Silat Hulu, Kapuas Hulu, Kalimantan Barat. J. Gizi dan Diet. Indones. 3, 119-130 (2015).

29. Puspasari, N. \& Andriani, M. Hubungan Pengetahuan lbu tentang Gizi dan Asupan Makan Balita dengan Status Gizi Balita (BB/U) Usia 12-24 Bulan. Amerta Nutr. 1, 369-378 (2017).

30. Mentari, S. \& Hermansyah, A. Faktor-faktor yang Berhubungan dengan Status Stunting Anak Usia 24-59 Bulan di Wilayah Kerja UPK Puskesmas Siantan Hulu. Pontianak Nutr. J. 1, 1-5 (2018).

31. Adriani, M. \& Wirjatmadi, B. Gizi dan Kesehatan Balita Peranan Mikro Zinc pada Pertumbuhan Balita. (Prenadamedia Group, 2014).

32. Aini, E. N., Nugraheni, S. A. \& Pradigdo, S. F. Faktor yang Mempengaruhi Stunting Pada Balita 
Usia 24-59 Bulan Di Puskesmas Cepu Kabupaten Blora. J. Kesehat. Masy. 6, (2018).

33. Mitra. Problems and Interventions to Prevent Stunting (A Literature Review). J. Kesehat. Komunitas 2, 254-261 (2015).

34. Wibowo. \& Herdian, K. A. Hubungan Asupan Kalsium Dan Pendidikan Ibu Dengan Kejadian Stunting Pada Anak Di Madrasah Ibtidaiyah Muhammadiyah, Kartasura. (2018).
35. Aridiyah, F. O., Rohmawati, N. \& Ririanty, M. Faktor-faktor yang Mempengaruhi Kejadian Stunting pada Anak Balita di Wilayah Pedesaan dan Perkotaan. J. Pustaka Kesehat. 3, 163-170 (2015).

36. Ngaisyah, R. D. \& Septriana. Hubungan Tinggi Badan Orang Tua dengan Kejadian Stunting. J. Ilmu Kebidanan 3, 49-57 (2016).

37. Supariasa. Penilaian Statuz Gizi. (EGC, 2013). 